\title{
STRATEGI PENATAAN DAN PENGEMBANGAN SENTRA PRODUKSI PETERNAKAN KABUPATEN KOLAKA TIMUR
}

\author{
Musram Abadi ${ }^{1}$, La Ode Nafiu ${ }^{1}$, Lukman Yunus ${ }^{2}$ dan Fatmawati ${ }^{3}$ \\ ${ }^{1}$ Fakultas Peternakan Universitas Halu Oleo Jl. HEA. Mokodompit Kendari \\ ${ }^{2}$ Fakultas Pertanian Universitas Halu Oleo Jl. HEA Mokodompit Kendari \\ ${ }^{3}$ Fakultas Pertanian Universitas Nahdlatul Ulama Sultra Kendari \\ Email:musram.abadi8@gmail.com
}

\begin{abstract}
ABSTRAK
Penelitian ini bertujuan untuk mengidentifikasi potensi pengembangan sentra produksi peternakan Kabupaten Kolaka Timur dan sebagai arahan prioritas pembangunan dan pengembangan sentra peternakan Kabupaten Kolaka Timur. Penelitian ini dilaksanakan pada bulan September sampai dengan Oktober tahun 2017. Variabel dalam penelitian adalah (a) kekuatan, (c) kelemahan, (d) peluang dan (e) tantangan/hambatan pada penataan dan pengembangan sentra produksi peternakan serta alat analisis dalam penelitian ini adalah analisis SWOT.

Hasil penelitian menunjukkan bahwa strategi penataan dan pengembangan sentra produksi peternakan di Kabupaten Kolaka Timur antara lain; (a) Kebijakan pembangunan sarana dan prasarana kawasan peternakan difokuskan pada pengembangan jaringan irigasi, pembangunan dan perbaikan infrastruktur jalan sekitar kawasan, pembangunan jalan usahatani, pasar pengumpul desa, pasar pengumpul antar desa, kebutuhan jaringan listrik dan telekomunikasi dan fasilitas yang dibutuhkan untuk pengembangan industri pengolahan hasil-hasil peternakan, serta penyediaan sarana produksi seperti pupuk dan obat-obatan, dan $(b)$ kebijakan pengembangan sentra produksi peternakan yakni berupa penetapan dan perluasan padang penggembalaan dan lahan hijauan pakan ternak, manajemen pengelolaan, perbaikan budidaya ternak baik ternak besar, ternak kecil maupun unggas melalui sistem perkandangan, dan penyediaan pakan bagi ternak.
\end{abstract}

Kata Kunci : Strategi penataan dan pengembangan, sentra produksi Peternakan.

\begin{abstract}
This study aimed to identify the potency of livestock center development in Kolaka Timur Regency as well the priority purpose of improving and developing the livestock center in Kolaka Timur Regency. The research was conducted from September to October 2017. Measured variables were (a) strengths, (b) weaknesses, (c) opportunities, and (d) threats on organizing and developing the livestock production center, analyzed by using the SWOT analysis. Result of the study highlighted that strategy of organizing and developing the livestock production center in Kolaka Timur Regency including (a) the policy of facilities construction was focused on expanding of irrigation canal, construction and improvement of pathway surrounding the area, development of farming road, village collector market, collector market among villages, electricity and telecommunication system needs, and facilities required for expanding the industry of livestock products processing, and the providing of producing facilities such as fertilizers and cures, and (b) the policy to improve the livestock production center including assignment and expanding of grazing and land pasture, management system, improving the livestock breeding both ruminant and poultry through the housing system and feed management.
\end{abstract}

Key words: Strategy of organizing and developing, livestock production center

\section{PENDAHULUAN}

Strategi penataan dan pengembangan sentra produksi peternakan merupakan salah satu bentuk perencanaan untuk sektor strategis yang diharapkan dapat mendorong percepatan peningkatan nilai tambah yang diikuti dengan peningkatan produksi pada sentra-sentra produksi dari subsektor peternakan yang didukung oleh sarana dan prasarana yang relevan. Konsep ini dapat berdiri diri dan ataupun menyatu dalam satu Kawasan lebih luas (beberapa bagian wilayah kecamatan), tergantung dari potensi sentra produksi (fungsi kawasan) serta faktor jarak geografis dan faktor jarak aksesibilitas. 
Faktor jarak aksesibilitas sangat berperan di dalam menentukan orientasi suatu kawasan, terutama kawasan potensial yang jauh dari pusat pengembangannya, sehingga penentuan kawasan sentra produksi tidak lagi dipengaruhi oleh batas administratif (Soemarno, 2011).

Berdasarkan data statistik Kabupaten Kolaka Timur tahun 2017, bahwa jumlah populasi ternak besar sebanyak 12.333 ekor terbagi atas sapi 12.277 ekor dan kerbau 54 ekor. Sedang untuk populasi ternak kecil sebanyak 17.926 ekor terdiri atas: kambing 2.781 ekor dan babi 15.145 ekor. Semetara untuk ternak unggas sebanyak 455.235 ekor, meliputi: ayam kampung 423.765 ekor Ayam Ras 25.800 dan itik atau manila 5.670 ekor (Kabupaten Kolaka Timur Dalam Angka, 2017).

Dalam rangka penataan dan pengembangan sentra produksi peternakan harus didukung dengan perencanaan pengembangan melalui agribisnis peternakan. Agribisnis merupakan salah satu sektor dalam melakukan kegiatan perekonomian yang berbasis pada usaha pertanian secara umum atau bidang lain yang mendukungnya (Kurniawan, 2013). Pengembangan Agribisnis peternakan harus dipandang sebagai suatu sistem penyeluruh yang meliputi lahan, perbibitan, budidaya, industri pengolahan hasil peternakan dan berbagai usaha pendukung peternakan yang memang sudah saatnya tumbuh dan berkembang (Eviyati, 2005). Olehnya itu, perlu adanya dan kebijakan strategis pengembangan sentra peternakan melalui penelitian Strategi Penataan dan Pengembangan Sentra Produksi Peternakan Kabupaten Kolaka Timur".

\section{MATERI DAN METODE}

Lokasi penelitian ini adalah seluruh wilayah kecamatan di Kabupaten Kolaka Timur, yang difokuskan pada lokasi yang memiliki potensi peternakan, dengan metode pemilihan sampel lokasi secara purposive sampling (Komariah dan Satori, 2010). Sementara responden dalam penelitian ini adalah peternak serta pihak lain yang terkait (Dinas Pertanian, Bappeda, Kelompok Tani/Peternak, BP3K). Sampel responden akan dipilih secara purposive sampling. Alat analisis yang digunakan adalah analisis SWOT. Dengan demikian perencanaan strategis (strategic planner) harus menganalisis faktor-faktor strategis (kekuatan, kelemahan, peluang, dan ancaman) dalam kondisi yang ada saat ini (Rangkuti, 2009; Hunger dan Wheelen, 2003;Umar, 2001). Strategi didefinisikan sebagai suatu pendekatan yang diperlukan dalam perencanaan dan pelaksanaan suatu kegiatan (Mulatmi, 2016). Lanjut, David (2002) menyatakan strategi merupakan cara untuk mencapai sasaran jangka panjang untuk mecapai tujuan usaha, program tindaklanjut serta prioritas alokasi sumber daya.

\section{HASIL DAN PEMBAHASAN}

\section{A. Identifikasi dan Analisis Faktor Internal dan Eksternal}

Pengembangan sentra produksi peternakan yang dicanangkan pemerintah memberikan spirit kepada masyarakat sekaligus menjadi penggerak utama pembangunan ekonomi daerah di kabupaten Kolaka Timur. Hal ini sejalan dengan pendapat Muyassir (2010), peran strategis peternakan berkaitan dengan penanggulangan kemiskinan, untuk perlu diambil langkah-langkah antisipatif berupa pola penataan dan pengembangan kawasan peternakan industri dan peternakan rakyat secara proporsional.

Hasil Identifikasi faktor pendukung dan penghambat dalam penyusunan strategi penataan dan pengembangan sentra produksi peternakan di Kabupaten Kolaka Timur, dilakukan melalui pengolahan data dan informasi yang diperoleh dari responden. Adapun hasil analisis Internal Factor Evaluation (IFE) dan Ekstenal Faktor Evaluation (EFE) pada penataan dan pengembangan sentra produksi peternakan dilihat Tabel 2. 
Tabel 2. Matriks Internal Factor Evaluation (IFE) dan Ekstenal Faktor Evaluation (EFE)

\begin{tabular}{|c|c|}
\hline Faktor-Faktor Internal & $\begin{array}{c}\text { Rata-Rata } \\
\text { BobotxRangking }\end{array}$ \\
\hline \multicolumn{2}{|l|}{ Kekuatan } \\
\hline 1. Pengalaman Peternakan yang cukup tinggi & 0.444 \\
\hline 2. Ketersediaan lahan yang cukup memadai & 0.425 \\
\hline 3. Adanya kemudahan dalam memasarkan ternak & 0.233 \\
\hline 4. Ketersediaan pakan yang cukup memadai & 0.339 \\
\hline 5. Ketersediaan tenaga kerja yang cukup tinggi & 0.403 \\
\hline Total & 1.844 \\
\hline \multicolumn{2}{|l|}{ Kelemahan } \\
\hline 1. Tingkat pendidikan peternakan yang masih rendah & 0.136 \\
\hline 2. Skala kepemilikan yang masih rendah (2-3 ekor/peternak) & 0.153 \\
\hline 3. Pemanfaatan teknologi pakan yang masih rendah & 0.133 \\
\hline 4. Rendahnya kepemilikan modal usaha & 0.119 \\
\hline 5. Kelembagaan peternak yang belum berfungsi secara optimal & 0.128 \\
\hline Total & 0.669 \\
\hline Faktor-Faktor Eksternal & $\begin{array}{c}\text { Rata-Rata } \\
\text { BobotxRangking }\end{array}$ \\
\hline \multicolumn{2}{|l|}{ Peluang } \\
\hline 1. Permintaan pasar yang cukup tinggi & 0.479 \\
\hline 2. Minat masyarakat untuk beternak yang cukup tinggi & 0.274 \\
\hline 3. Akses pemasaran melalui kemudahan komunikasi dan informasi & 0.148 \\
\hline 4. Adanya kebijakan pemerintah mendukung pengembangan peternakan & 0.153 \\
\hline 5. Ketersediaan bahan baku lokal berupa jagung dan dedak masih melimpah & 0.294 \\
\hline $\begin{array}{c}\text { Total } \\
\end{array}$ & 1.349 \\
\hline \multicolumn{2}{|l|}{ Ancaman } \\
\hline 1. Harga produk peternakan dan harga pakan yang selalu berfluktuasi & 0.507 \\
\hline 2. Adanya alih fungsi lahan sebagai lahan pertanian & 0.432 \\
\hline 3. Penanganan kesehatan ternak yang belum optimal & 0.309 \\
\hline 4. Penguasaan teknologi yang masih rendah & 0.195 \\
\hline 5. Rendahnya produktivitas peternakan & 0.103 \\
\hline Total & 1.546 \\
\hline
\end{tabular}

Sumber: Hasil Analisis Data, 2017

Berdasarkan hasil analisis Internal Factor Evaluation (IFE) diperoleh nilai dengan rata-rata 1.349 dan hasil analisis Ekstenal Faktor Evaluation (EFE) diperoleh nilai rata-rata 1.546 , selanjutnya dilakukan analisis IE dan SWOT. Menurut Musram, A., dkk, (2016), bahwa penyusunan matriks IE bertujuan untuk memperoleh strategi ditingkat yang lebih detail. Matriks internal dan eksternal (IE) mengindikasikan 9 sel strategi tetapi umumnya sel tersebut dapat dikelompokkan menjadi tiga strategi utama untuk mempermudah dalam pemilihan alternatif strategi. Untuk lebih jelasnya sesuai yang terdapat dipada gambar 1 .

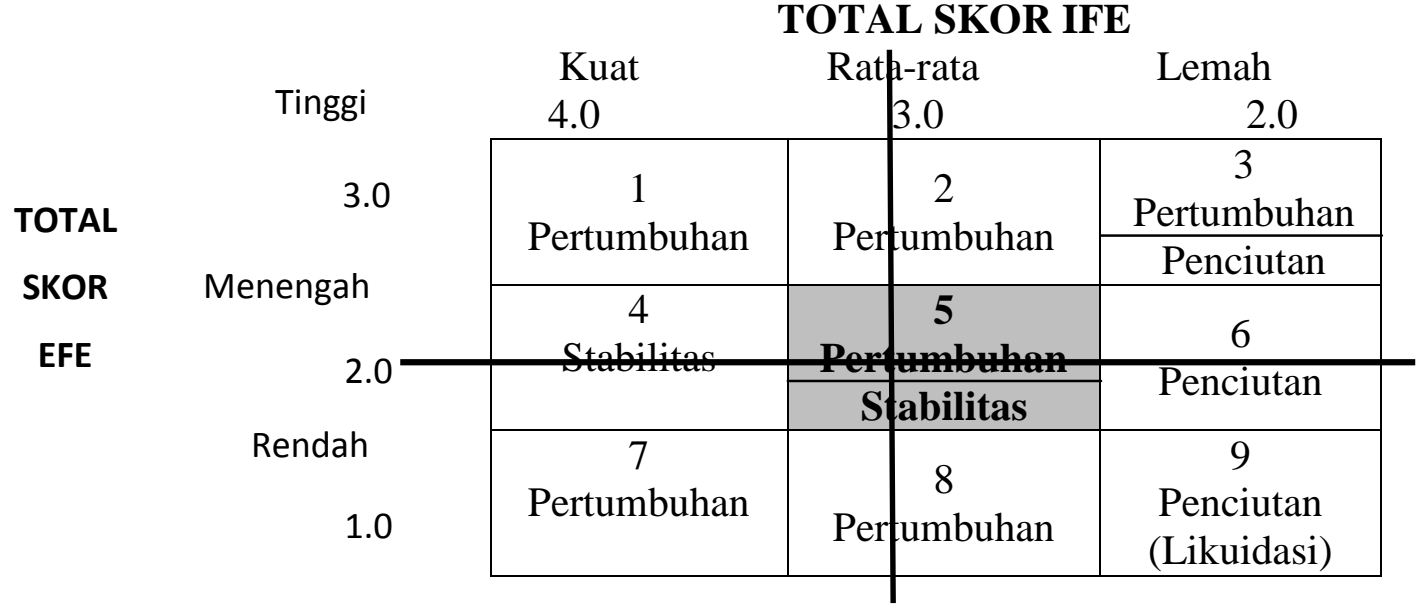

Gambar 1. Matriks Internal-Eksternal Pengembangan Peternakan Kabupaten Kolaka Timur 


\section{B. Analisis Matriks SWOT}

Berdasarkan analisis Internal Factor Evaluation (IFE) dan Ekstenal Faktor Evaluation (EFE) berada pada kondisi sedang bertumbuh yang cenderung melakukan konsentrasi melalui melalui strategi intensif untuk mencapai kondisi stabilitas. Adapun strategi penataan dan pengembangan sentra produksi peternakan dapat dilihat pada Tabel 3 .

Tabel 3. Matriks Analisis SWOT Penataan dan Pengembangan Sentra Produksi Peternakan Kabupaten Kolaka Timur

\begin{tabular}{|c|c|c|}
\hline \multirow[b]{2}{*}{ INTERNAL } & STRENGTHS (S) & WEAKNESSES (W) \\
\hline & $\begin{array}{l}\text { 1. Pengalaman } \\
\text { Peternakan yang } \\
\text { cukup tinggi } \\
\text { 2. Ketersediaan lahan } \\
\text { yang cukup memadai } \\
\text { 3. Adanya kemudahan } \\
\text { dalam memasarkan } \\
\text { ternak } \\
\text { 4. Ketersediaan pakan } \\
\text { yang cukup memadai } \\
\text { 5. Ketersediaan tenaga } \\
\text { kerja yang cukup } \\
\text { tinggi }\end{array}$ & $\begin{array}{l}\text { 1. Tingkat pendidikan } \\
\text { peternakan yang } \\
\text { masih rendah } \\
\text { 2. Skala kepemilikan } \\
\text { yang masih rendah } \\
\text { (2-3 ekor/peternak) } \\
\text { 3. Pemanfaatan } \\
\text { teknologi pakan yang } \\
\text { masih rendah } \\
\text { 4. Rendahnya } \\
\text { kepemilikan modal } \\
\text { usaha } \\
\text { 5. Kelembagaan } \\
\text { peternak yang belum } \\
\text { berfungsi secara } \\
\text { optimal }\end{array}$ \\
\hline OPPORTUNITIES (O) & STRATEGI - SO & STRATEGI - WO \\
\hline $\begin{array}{l}\text { 1. Permintaan pasar yang cukup tinggi } \\
\text { 2. Minat masyarakat untuk beternak yang } \\
\text { cukup tinggi } \\
\text { 3. Akses pemasaran melalui kemudahan } \\
\text { komunikasi dan informasi } \\
\text { 4. Adanya kebijakan pemerintah yang } \\
\text { mendukung pengembangan peternakan } \\
\text { 5. Ketersediaan bahan baku lokal berupa } \\
\text { jagung dan dedak masih melimpah }\end{array}$ & $\begin{array}{l}\text { a. Peningkatan kualitas } \\
\text { sarana dan prasarana } \\
\text { pendukung } \\
\text { pengembangan } \\
\text { sentra produksi } \\
\text { peternakan } \\
\text { b. Optimalisasi } \\
\text { pemanfaatan limbah } \\
\text { pertanian sebagai } \\
\text { pakan ternak yang } \\
\text { jumlahnya } \\
\text { melimpah. }\end{array}$ & $\begin{array}{l}\text { a. Penguatan kapasitas } \\
\text { peternakan dalam } \\
\text { mengembangkan } \\
\text { usahanya } \\
\text { b. Penerapan teknologi } \\
\text { pengolahan pakan } \\
\text { berbasis limbah } \\
\text { pertanian }\end{array}$ \\
\hline $\begin{array}{c}\text { TREATHS (T) } \\
\end{array}$ & STRATEGI S-T & STRATEGI W-T \\
\hline $\begin{array}{l}\text { 1. Harga produk peternakan dan harga } \\
\text { pakan yang selalu berfluktuasi } \\
\text { 2. Adanya alih fungsi lahan sebagai lahan } \\
\text { pertanian } \\
\text { 3. Penanganan kesehatan ternak yang } \\
\text { belum optimal } \\
\text { 4. Penguasaan teknologi yang masih } \\
\text { rendah } \\
\text { 5. Rendahnya produktivitas peternakan }\end{array}$ & 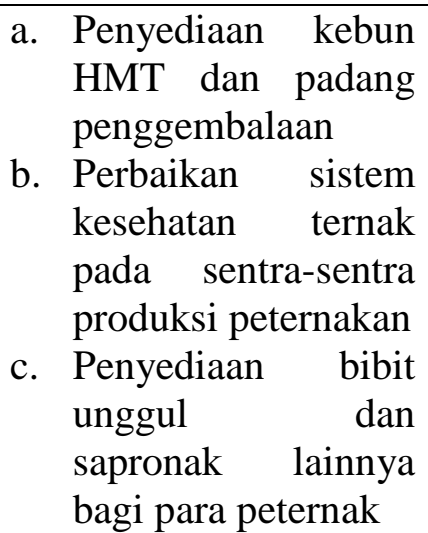 & $\begin{array}{ll}\text { a. } & \text { Penyediaan pasar } \\
\text { ternak pada sentra } \\
\text { produksi peternakan } \\
\text { b. } \begin{array}{ll}\text { Penguatan } \\
\text { kelembagaan }\end{array} \\
\text { peternak } \\
\text { c. Penyediaan kredit } \\
\text { modal } & \text { usaha } \\
& \text { peternakan }\end{array}$ \\
\hline
\end{tabular}

Sumber : Hasil Analisis Data, 2017. 
Berdasarkan hasil analisis pada Matriks SWOT diatas, maka dilahirkan strategi-strategi dalam penataan dan pengembangan sentra produksi peternakan di Kabupaten Kolaka Timur, selanjutnya ditetapkan kebijakan strategis yaitu (a) Kebijakan pembangunan sarana dan prasarana kawasan peternakan difokuskan pada pengembangan jaringan irigasi, pembangunan dan perbaikan infrastruktur jalan sekitar kawasan, pembangunan jalan usahatani, pasar pengumpul desa, pasar pengumpul antar desa, kebutuhan jaringan listrik dan telekomunikasi dan fasilitas yang dibutuhkan untuk pengembangan industri pengolahan hasil-hasil pertanian, serta penyediaan sarana produksi seperti pupuk dan obat-obatan, dan (b) kebijakan pengembangan sentra produksi peternakan yakni berupa penetapan dan perluasan padang penggembalaan dan lahan hijauan pakan ternak, manajemen pengelolaan, perbaikan budidaya ternak baik ternak besar, ternak kecil maupun unggas melalui sistem perkandangan, dan penyediaan pakan bagi ternak.

\section{KESIMPULAN}

Adapun kesimpulan dari hasil penelitian mengenai strategi penataan dan pengembangan sentra produksi peternakan di Kabupaten Kolaka Timur antara lain;

(a) Kebijakan pembangunan sarana dan prasarana kawasan peternakan difokuskan pada pengembangan jaringan irigasi, pembangunan dan perbaikan infrastruktur jalan sekitar kawasan, pembangunan jalan usahatani, pasar pengumpul desa, pasar pengumpul antar desa, kebutuhan jaringan listrik dan telekomunikasi dan fasilitas yang dibutuhkan untuk pengembangan industri pengolahan hasil-hasil peternakan, serta penyediaan sarana produksi seperti pupuk dan obat-obatan.

(b) kebijakan pengembangan sentra produksi peternakan yakni berupa penetapan dan perluasan padang penggembalaan dan lahan hijauan pakan ternak, manajemen pengelolaan, perbaikan budidaya ternak baik ternak besar, ternak kecil maupun unggas melalui sistem perkandangan, dan penyediaan pakan bagi ternak

\section{DAFTAR PUSTAKA}

Aan Komariah dan Djam'an Satori, 2010. Metodologi Penelitian Kualitatif Bandung : Alfabeta.

Achmadi dan I. Las. 2006. Inovasi teknologi pengembangan pertanian lahan rawa lebak. Prosiding Seminar Nasional Pengelolaan Lahan Terpadu, Banjarbaru, 28-29 Juli 2006. Hal. 2136.

Badan Pusat Statistik, 2017. Kolaka Timur Dalam Angka 2016. Kabuaten Kolaka Timur.

David, F. R. 2002. Manajemen Stategis : Konsep. PT. Prenhallindo, Jakarta.

Eviyati, R, 2005. Tinjauan Agribisnis Peternakan. Jurnal AGRIJATI Vol. 1 No. 1, Hal. 31-37

Hunger, J.D. dan Th.L. Wheelen, 2003. Manajemen Strategis. Terjemahan. Penerbit Andi, Yogyakarta.

Kurniawan, M. Fajar Trisna, Dwi Putra Darmawan, N.W. Sri Astiti, 2013. Strategi pengembangan Agribisnis Peternakan Ayam Petelur di Kabupaten Tabanan. Jurnal Manajemen Agribisnis Vol. 1, No. 2, Hal. 53-66.

Mulatmi, Septi, Nur, Wulan, Budi Guntoro, Budi Prasetyo Widyobroto, Sudi Nurtini, Ambar Pertiwiningrum, 2016. Strategi Peningkatan Adopsi Inovasi Pada Peternakan Sapi Perah Rakyat di Daerah Istimewa Yogyakarta, Jawa Tengah, dan Jawa Timur. Buletin Peternakan Vol. 40, No. 3, Hal. 219-227.

Musram Abadi., Sitti Aida Adha Taridala dan La Ode Nafiu, 2016. Strategi pengembangan agribisnis ayam ras petelur pada cv. Bintani poultry shop kendari. Jurnal JITRO Vol. 3 : 20-31.

Muyassir, 2010. Analisis Potensi Sumberdaya Lahan Untuk Pengembangan Peternakan Kabupaten Aceh Besar. Jurnal Lentera Vol. 10, No. 1, Hal. 17-28.

Rangkuti, Freddy, 2009. Strategi Promosi yang Kreatif dan Analisis Kasus Integrated Marketing Communication. Jakarta : PT. GramediaPustakaUtama.

Soemarno, 2011. Model Perencanaan, Kawasan Sentra Produksi Agribisnis (KSPA). Bahan Ajar. Samarinda.

Umar, H, 2001. Strategic Manajemen in Action. PT. Gramedia Pustaka Utama. Jakarta 